\title{
Postauricular congenital alveolar rhabdomyosarcoma- a case report of an unusual entity Mahesha Vankalakunti ${ }^{1}$, Ashim Das*1 and Narasimhan KL Rao ${ }^{2}$
}

Address: ${ }^{1}$ Department of Histopathology, Postgraduate Institute of Medical Education \& Research, Chandigarh, India and ${ }^{2}$ Department of Pediatric surgery, Postgraduate Institute of Medical Education \& Research, Chandigarh, India

Email: Mahesha Vankalakunti - vkmahesh123@yahoo.co.in; Ashim Das* - ashim126@gmail.com; Narasimhan KL Rao - klnrao@yahoo.co.in

* Corresponding author

Published: 17 October 2006

Diagnostic Pathology 2006, I:37 doi:10.1 186/1746-1596-1-37

This article is available from: http://www.diagnosticpathology.org/content/l/1/37

(C) 2006 Vankalakunti et al; licensee BioMed Central Ltd.

This is an Open Access article distributed under the terms of the Creative Commons Attribution License (http://creativecommons.org/licenses/by/2.0), which permits unrestricted use, distribution, and reproduction in any medium, provided the original work is properly cited.
Received: 26 August 2006

Accepted: 17 October 2006

\begin{abstract}
Background: Congenital alveolar rhabdomyosarcoma is an extremely uncommon and invariably fatal tumor with the current therapy. Less than $25 \%$ of patients present with evidence of cutaneous metastasis.

Case presentation: We report a case of congenital alveolar rhabdomyosarcoma in an 18-monthold male who presented with a progressively increasing mass lesion in the left post-auricular region since birth. Radiological examination did not show any intracranial involvement of the mass lesion. Upon resecting the mass that was $10-\mathrm{cm}$ in largest dimension, the gross, microscopic, and ultrastructural findings were consistent with congenital alveolar rhabdomyosarcoma.

Conclusion: The suspicion of alveolar subtype on histological grounds and proper evaluation of this tumor by immunostain and ultrastuctural examination is necessary. In the Medline literature search, there is no report of large congenital alveolar rhabdomyosarcoma in the post-auricle region.
\end{abstract}

\section{Background}

Although rhabdomyosarcoma (RMS) is an uncommon childhood malignancy, it is the most frequently encountered soft tissue sarcoma found in infants and children [1]. Six percent of all RMS cases occur in children age $<1$ year at the time of diagnosis [2,3]. RMS is slightly more common in males than females (range, 1.3-1.4: 1). The head and neck, extremities, genitourinary tract, and trunk are the most common primary sites. Overall, $<25 \%$ of patients have metastatic spread at the time of diagnosis, with the most common sites including the lung, lymph nodes, bone, and bone marrow.

Congenital alveolar RMS, defined as disease present at birth, is a rare subtype of RMS. We present a case of con- genital alveolar RMS, which was completely resected at the age of 18 months.

\section{Case report}

An eighteen-month-old male child presented with a mass lesion in the left post-auricle region. The mass was present at birth and was gradually increasing in size. The measurement of the mass was $10 \times 6 \times 4 \mathrm{~cm}$. The skin over it was unremarkable, and the other systemic examination was within normal limits. A non-contrast computed tomography of head and neck revealed the mass in the left postauricular region (Figure 1). There was no intracranial involvement. 


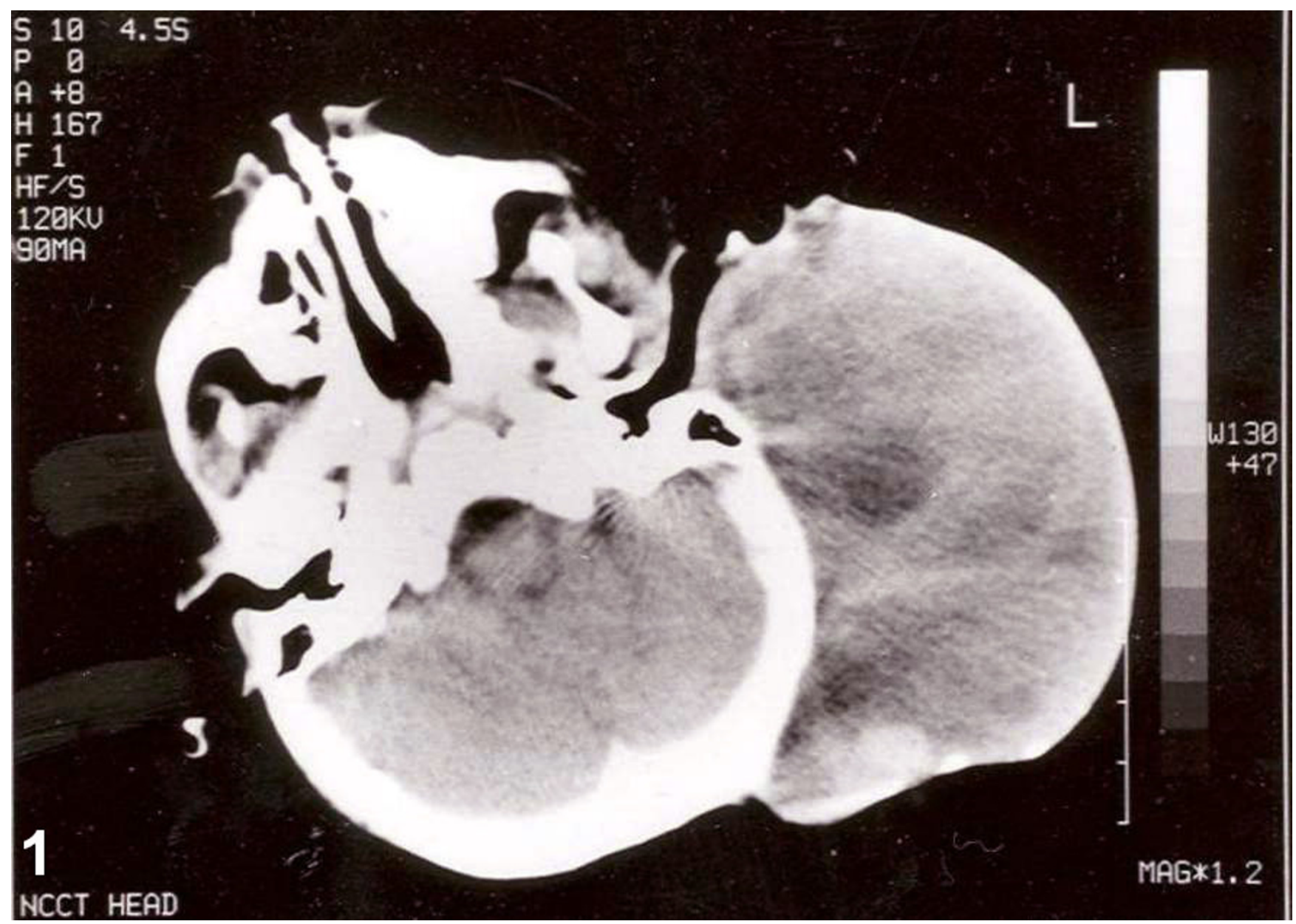

Figure I

Non-contrast computed tomography of head showing the hypoechoeic mass without any intracranial extension.

A histologic diagnosis of congenital alveolar rhabdomyosarcoma (RMS) was made after complete excision of the mass. Grossly, the mass was fairly well circumscribed, multinodular with a glistening, gelatinous gray-white surface. Cystic areas were seen in between (Figure 2). Neither haemorrhage nor necrosis was present.

Microscopically, it revealed a varying degree of cellularity with densely packed cellular areas separated by a framework of hyalinized fibrous septa. The tumor cells were discohesive in the centre. The individual cells were large, round with darkly staining hyperchromatic nuclei, inconspicuous nucleoli, and scant indistinct cytoplasm (Figure $3)$. High mitotic rate was noticed. The tumor cells $(\approx 40 \%)$ were positive for desmin and myogenin (Figure 4 ) immunostains. The other panels of immunostains used were CD45, CD20, MIC-2, CK, Neuron specific enolase, and myeloperoxidase, all of which were negative.
Ultrastructuraly, the tumor cells showed few cytoplasmic organelles and occasional bundles of thin myofilaments measuring 4-6 nm in diameter. Bone marrow examination didn't reveal any metastatic deposit. A cytogenetic analysis was not performed because of technical reasons. In the one year follow-up period, there has been no recurrence or metastatic deposit.

\section{Discussion}

Rhabdomyosarcoma (RMS), a malignant tumor originating from skeletal muscle, usually occurs in the first two decades of life. The vast majority of RMS occurs in head and neck region, extremities, genitourinary system and trunk. RMS bears a close resemblance to various stages in the embryogenesis of normal skeletal muscle, but its pattern is much more variable and ranges from poorly differentiated tumours that are very difficult to diagnose without immunohistochemical or electron microscopic examination to a well-differentiated RMS. 


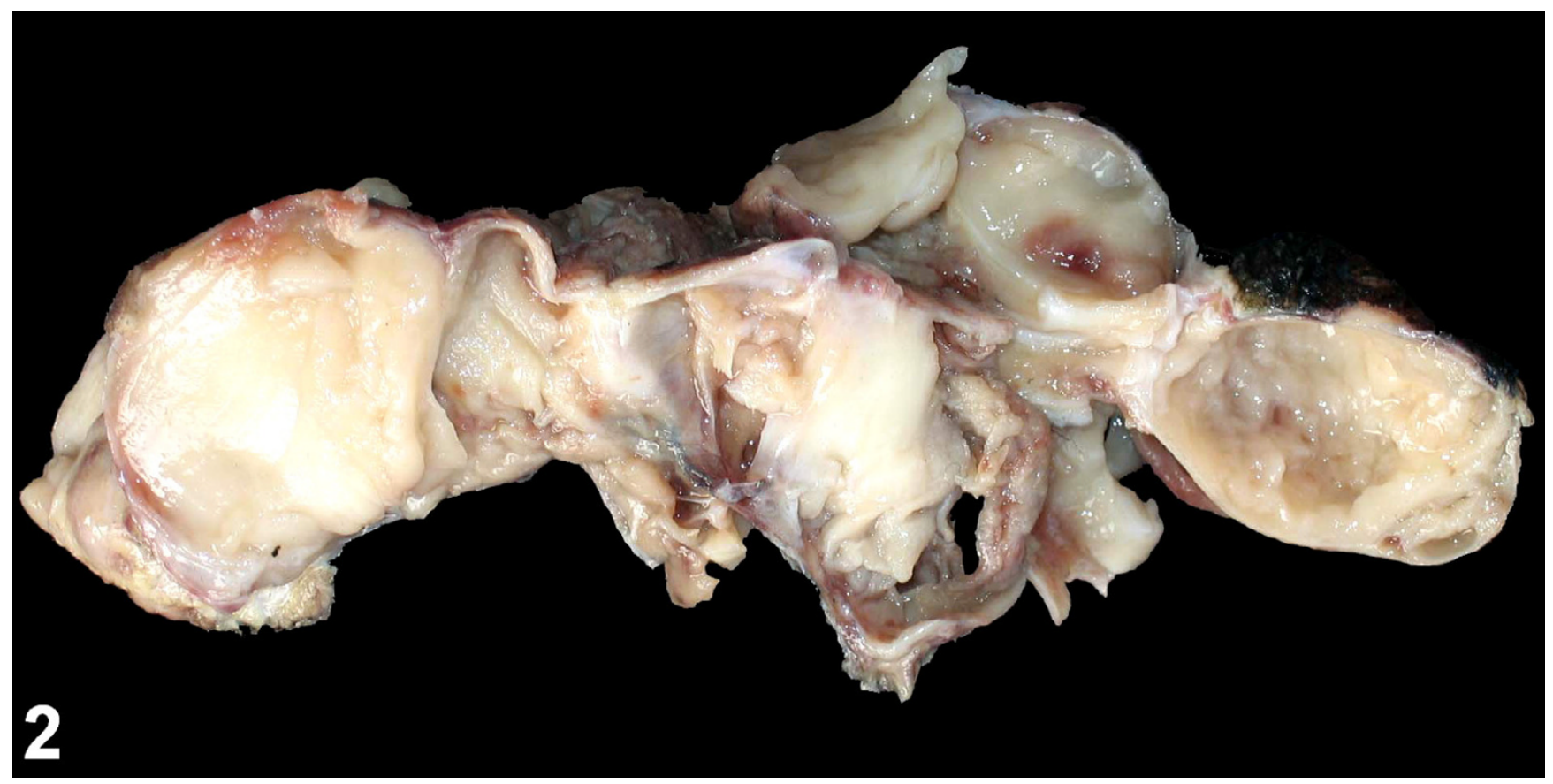

Figure 2

Gross specimen revealing glistening gelatinous gray-white cut surface with cystic areas.

A retrospective study has shown the incidence of tumours in the neonatal period to be 7.2 per 100,000 live births per year $(1: 13,700)[3]$. In the same study, soft tissue tumours represented $17 \%$ of all tumours presenting within the first month of life; however, the majority of these tumours (65\%) were histologicaly benign [6]. Overall, $<1 \%$ of all patients with RMS present with the disease within the first month of life and in these cases the histology predominantly is of the embryonal sub-type [3-6]. Alveolar RMS is characterized by specific chromosomal translocations, the majority of which are the $\mathrm{t}(2 ; 13)(\mathrm{q} 35 ; \mathrm{q} 14)$ translocation.

Only a few cases (less than 20) have been reported in the literature about alveolar subtype of congenital rhabdomyosarcoma. Alveolar RMS has been previously described in the region of the eyes, ears, infratemporal, cervical and parameningeal regions in neonates and children [7]. But to the best of our knowledge, there has been no record of congenital alveolar RMS in the post-auricle region.

Our case belongs to Group II of clinical staging (Intergroup Rhabdomyosarcoma Studies Classification) [8]. The alveolar type, large size $(>5 \mathrm{~cm})$ and location are poor prognostic factors in our case. Morphologically, 'solid' forms of alveolar RMS can also be seen which might sim- ulate the round cell areas of embryonal RMS. However, uniform cellular pattern, multinucleate giant cells and incipient alveolar features, supported by cytogenetic studies help in differentiating between the two. All the morphological features mentioned above were seen in our case. It is important not to confuse the two, as the alveolar type carries a less favourable prognosis.

Differential diagnosis includes neuroblastoma, neuroepithelioma, extra skeletal Ewing's sarcoma, melanotic neuroectodermal tumour of infancy and malignant lymphoma.

The clinical management of neonates with malignancy presents considerable problems due to the physiologic immaturity of many organ systems in infants. Neonates in the Intergroup Rhabdomyosarcoma Studies Classification (IRS) study received $70 \%$ of the prescribed dose of the three principal agents used to treat RMS (cyclophosphamide, vincristine, and actinomycin D). Severe myelosuppression and infections were the principal side effects. It is interesting to note that our patient had no recurrence of the lesion or any metastatic deposit elsewhere at the end of one year follow-up. Surgery followed by the standard chemotherapy regimen was given according to the treatment plan. Grundy et al reported the longest survivor who 


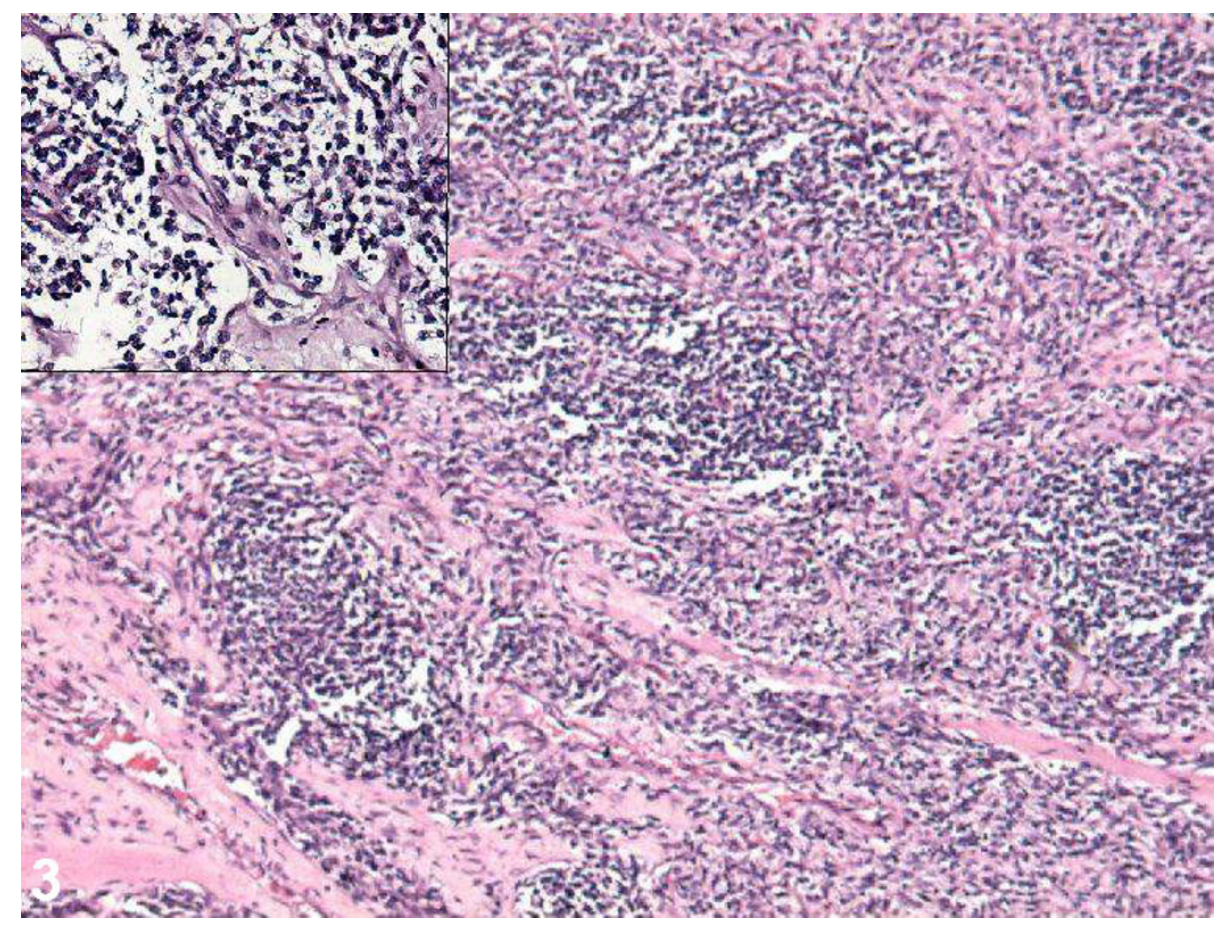

Figure 3

Photomicrograph showing nodules of tumor cells separated by hyalinised fibrous septae (50x, HE stain). Inset: Discohesive large tumor cells with hyperchromatic nucleus and scant cytoplasm (200x, HE stain).

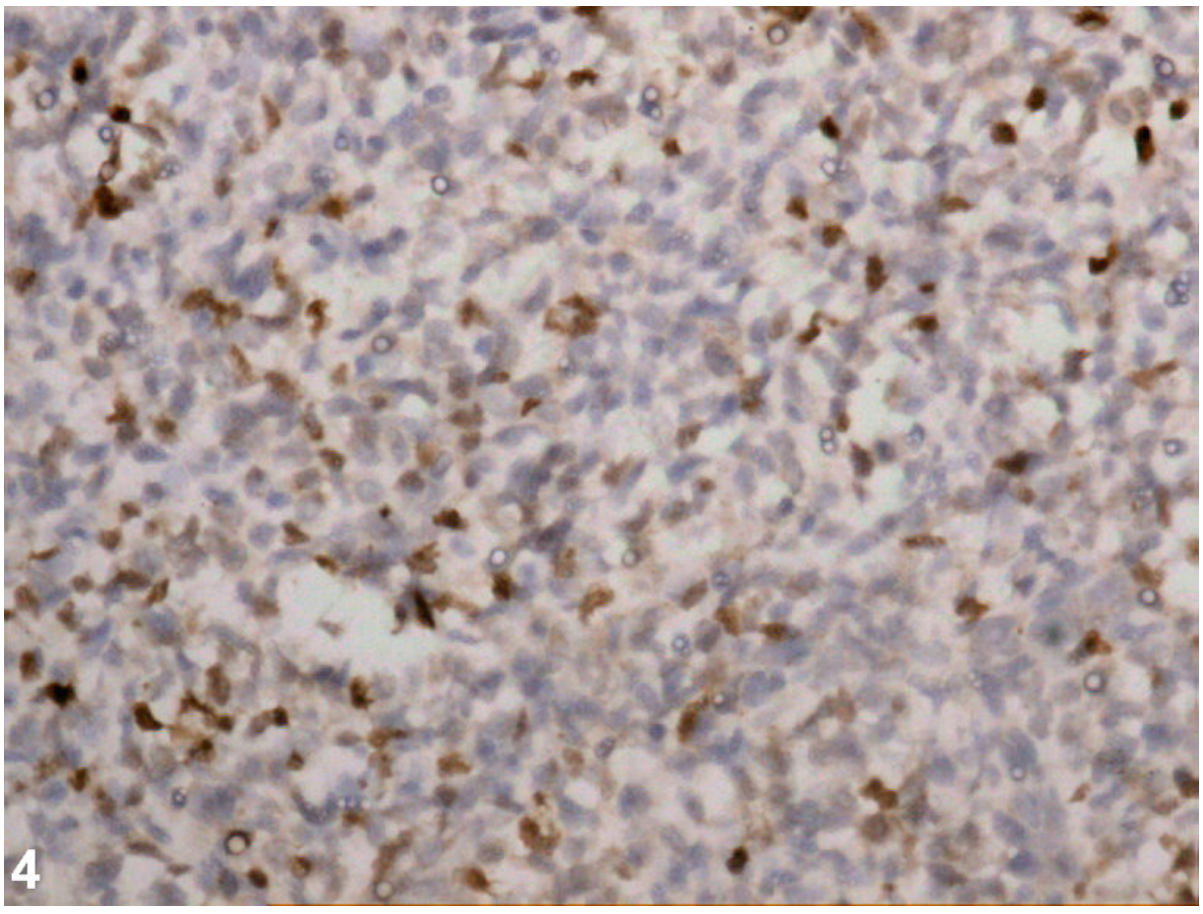

\section{Figure 4}

Myogenin immunostain revealing nuclear positivity (200x, immunoperoxidase). 
underwent myeloablative therapy with peripheral stem cell support, and hence suggest that more intensive treatment may be of value in this rare condition [9].

\section{Conclusion}

Our case exemplifies the rare sub-type of congenital RMS occurring in the post-auricular area. This is a highly malignant tumor with no record of long-term survivors. In this setting, clinical outcome and radiological findings must be accounted for by both pathologists and clinicians who must be aware of such an unusual presentation of congenital rhabdomyosarcoma, whose diagnosis requires representative tissue sampling and whose treatment may require an adjustment of drug dosage.

\section{Acknowledgements}

Written consent was obtained from the patient or their relative for publication of study.

\section{References}

I. Kilman JW, Clatworthy HW Jr, Newton WA Jr, Grosfeld JL: Reasonable surgery for rhabdomyosarcoma. Ann Surg 1973, 179:346-51.

2. Ragab A, Heyn R, Teftt M, Tefft M, Hays DN, Newton WA Jr, Beltangady $M$ : Infants younger than I year of age with rhabdomyosarcoma. Cancer 1986, 58:2606-10.

3. Koscielniak E, Harms D, Schmidt D, Ritter J, Keim M, Riehm H, Treuner J: Soft tissue sarcomas in infants younger than I year of age: a report of the German soft tissue sarcoma study group (CWS-81). Med Pediatr Oncol 1989, 17:105-10.

4. Parkes SE, Muir KR, Southern L, Cameron AH, Darbyshire PJ, Stevens MC: Neonatal tumours: a thirty year population-based study. Med Pediatr Oncol 1994, 22:309-17.

5. Coffin CM, Dehner LP: Soft tissue tumors in first year of life: a report of 190 cases. Pediatr Pathol 1990, I0(4):509-26.

6. Lobe TE, Wiener ES, Hays DM, Lawrence WH, ANdrassy RJ, Johnston J, Wharam M, Webber B, Ragab A: Neonatal rhabdomyosarcoma: the IRS experience. J Pediatr Surg 1994, 29: I 167-70.

7. Yoshino K, Takeuchi M, Nakayama M, Suehara N: Congenital cervical rhabdomyosarcoma arising in one fetus of a twin pregnancy. Fetal Diagn Ther 2005, 20(4):291-95.

8. Maurer HM, Beltangady M, Gehan EA, Crist W, Hammond D, Hays DM, Heyn R, Lawrence W, Newton W, Ortega J: The Intergroup Rhabdomyosarcoma Study-I: a final report. Cancer 1988, 6I:209-20.

9. Grundy R, Anderson J, Gaze M, Gerrard M, Glaser A, Gordon A, Malone M, Pritchard-Jones K, Michalski A: Congenital Alveolar Rhabdomyosarcoma: clinical and molecular distinction from alveolar rhabdomyosarcoma in older children. Cancer 200I, 91:606-12.

\section{Publish with Biomed Central and every scientist can read your work free of charge}

"BioMed Central will be the most significant development for disseminating the results of biomedical research in our lifetime. " Sir Paul Nurse, Cancer Research UK

Your research papers will be:

- available free of charge to the entire biomedical community

- peer reviewed and published immediately upon acceptance

- cited in PubMed and archived on PubMed Central

- yours - you keep the copyright

Submit your manuscript here:

http://www.biomedcentral.com/info/publishing_adv.asp
BioMedcentral 